\title{
Ozone as a Safety Post-Harvest Treatment for Chlorpyrifos Removal from Vegetables and its Effects on Vegetable Quality
}

\author{
Khaled, A. $\mathbf{O}^{1^{*}}$, Fahad, B ${ }^{2}$, Abdullah $\mathbf{A}^{2}$ \\ ${ }^{1}$ Department of Pesticide Chemistry \& Technology, Alexandria University, Alexandria, Egypt \\ ${ }^{2}$ Department of Food and Drug Authority, Laboratory Dept., Dammam, King Abdul-Aziz Port, KSA, Saudi
}

"Corresponding author: Khaled, A. O, Department of Pesticide Chemistry \& Technology, Alexandria University, Alexandria, Egypt; Tel.: +2035901900; Fax: +2035922780; E-mail: kamosman@yahoo.com

\begin{abstract}
The removal of chlorpyrifos pesticide residues from vegetables was achieved by using low level of ozonated water (OZW) for $15-60$ min as contact times at 25 and $35^{\circ} \mathrm{C}$. Recovered amount of chlorpyrifos was extracted using solid phase extraction (SPE) and then analyzed by gas chromatography-mass spectrometry (GC-MS). The initial levels of residual chlorpyrifos varied with the kind of vegetables, where arugula had the highest level followed by parsley, leek, tomato, carrot, cucumber, cabbage, and then bell pepper. When vegetables washed in OZW was at $25^{\circ} \mathrm{C}$, the percentages of chlorpyrifos removal were time-dependent and ranged from $30-83,91-97,80-92$, 92 - 95, 87 - 97, 95 - 97, 64 - 100 and 90 - 97\% for bell pepper, tomato, cucumber, carrot, arugula, parsley, cabbage and leek, respectively. In case of vegetables washed with $\mathrm{OZW}$ at $35^{\circ} \mathrm{C}$, increasing of the contact time was not significantly effect on the removal percentages of chlorpyrifos except with arugula and cabbage. Likewise, the increasing of OZW temperature caused a negative consequence on the removal percentages of pesticide. The effect of these wash treatments on vegetable quality parameters indicated that the removing of chlorpyrifos by using OZW did not produce any significant undesirable effects on antioxidant capacity, total phenolic contents and vitamin $\mathrm{C}$ of the tested vegetables.

Due to the large amount of vegetables consumed in fresh form, a higher risk of exposure to chlorpyrifos may occur and the search for a safety method to remove this pesticide with negligible residual deposits has always been preferred. Therefore, the present study validated that ozone technology as wash treatment is safe and promising processes for the removal of chlorpyrifos from the vegetable's surface under domestic conditions to reduce the impact over consumer's health.
\end{abstract}

Received Date: January 23, 2017

Accepted Date: February 27, 2017

Published Date: April 04, 2017

Citation: Khalid, A. O., et al. Ozone as a Safety Post-Harvest Treatment for Chlorpyrifos Removal from Vegetables and its Effects on Vegetable Quality. (2017) J Food Nutr Sci 4(1): 38- 48.

DOI: $10.15436 / 2377-0619.17 .1319$

Keywords: Chlorpyrifos; Vegetables; Ozone; Quality parameters; Safety

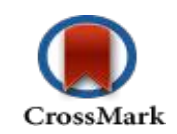

\section{Introduction}

Pesticides are a group of artificially synthesized substances used in farms to control pests and to enhance agricultural production. However, the use of pesticides represents a risk, especially in the developing countries. In recent years, the scientific community has shown a great concern about the possible adverse effects of these pesticides in food. These residues cause detrimental effects on human health such as neurotoxicity, carcinogenesis, abnormal reproduction and cell development ${ }^{[1,2]}$ (Burrows et al., 2002) especially in the developing countries where pesticide contamination is widespread ${ }^{[3]}$.
Chlorpyrifos (O, O-diethyl O-3, 5, 6-trichloro-2-pyridyl phosphorothioate) is a broad spectrum organo phosphorus (OP) insecticide, widely used in agriculture to control pests in soil or on foliage in over 100 crops as well as public health and acts as a non-systemic insecticide with contact, stomach, and respiratory action ${ }^{[4]}$. Despite recent restrictions on further production for use, chlorpyrifos remains the most widely used organophosphate pesticides, and there is increasing concern over the potential consequences of fetal and childhood exposures (Song et al. 1998). The acute toxicity of chlorpyrifos is mediated through inhibition of cholinesterase by the active metabolite chlorpyrifos oxon, and the consequent accumulation of the neu- 
rotransmitter acetylcholine (ACh) in synaptic junctions leads to excessive stimulation of postsynaptic cells causing cholinergic toxicity. Also, chlorpyrifos may induce intracellular oxidative stress (Osman 1999), influence brain cell replication (Crumpton et al. 2000) and DNA synthesis (Dam et al. 2000) as well as disrupts normal cellular development and differentiation (Bebe and Panemangalore, 2003).

In fact, fruits and vegetables are basic ingredients of the highly demanded diet, associated with a beneficial and healthy function against numerous diseases ${ }^{[6,7]}$. With increasing global demand for vegetables, buyers demand these vegetables with lower pesticide residues. The development of efficient strategies is necessary to reduce pesticide residues from agricultural products $^{[8]}$. Recently, many processes have been tested for degrading pesticides on various agricultural products. Some of these processes utilize powerful oxidizing agents such as $\mathrm{O}_{3} /$ electron beam $^{[9,10]}, \mathrm{O}_{3} / \mathrm{H}_{2} \mathrm{O}_{2}, \mathrm{UV} / \mathrm{O}_{3}{ }^{[11]}$ (Kuo, 1999), electrochemical oxidation processes ${ }^{[12,13]}$, UV, photo-Fenton system ${ }^{[14]}$, titanium dioxide catalytic treatment ${ }^{[15]}$, bio treatment ${ }^{[16]}$, microwave irradiation $^{[17]}, \mathrm{UV} / \mathrm{H}_{2} \mathrm{O}_{2}$ and ozonated water (Osman et al. 2014; Osman 2015). Hence, the use of such simple and non-toxic washing treatments to reduce such residues in fruit and vegetable samples can facilitate the commercialization and reduce the impact over the consumer health ${ }^{[18]}$. (Osman et al. 2014; Osman 2015).

$\mathrm{O}_{3}$ is a triatomic form of oxygen and is referred to as activated oxygen, allotropic oxygen or pure air and considered as a powerful oxidant, where it's higher oxidizing character $\left(\mathrm{E}_{0}\right)$ $=2.8 \mathrm{~V}$. It has a pungent, characteristic odor described as similar to "fresh air after a thunderstorm" ${ }^{[19]}$. It is an unstable gas with a half-life of in distilled water at $20^{\circ} \mathrm{C}$ is about $20-30 \mathrm{~min}$ and degrades quickly into oxygen and thus leaves no residues in food $^{[20]}$. Thus, it does not accumulate substantially without continual ozone generator ${ }^{[21]}$. These attributes make $\mathrm{O}_{3}$ in gaseous or liquid form as an attractive candidate for controlling insects and fungi in stored products, used even in fruits and vegetables (Carletti et al. 2013; Osman 2015) and extend the storage life of fruits and products ${ }^{[8,22,23]}$ Such advantages make ozone attractive to the food industry and therefore it has been affirmed as generally recognized as Safe (GRAS) for utilization in food processing ${ }^{[24]}$. Likewise, the preoxidation by ozone is an effective treatment for putting down the majority of the pesticides in many agricultural products ${ }^{[8,25,26]}$ (Ormad et al., 2008; Karaca et al., 2012; Kusvuran et al. 2012; Osman 2015). The removal efficiency of pesticides highly depends on the dissolved ozone level, temperature, $\mathrm{pH}$ level, type of pesticide and matrix ${ }^{[18,25,27]}$ (Kusvuran et al., 2012).

Because there is a general trend in KSA to increase the production of vegetables, mainly due to their health properties and the demand to use chlorpyrifos for control of insects in vegetables. This leads to pesticide residues on (or in) the vegetables at harvest. These residue levels are generally well higher than the established tolerances ${ }^{[1]}$. Recently, the safety of vegetables, including contamination with agricultural pesticides is a major concern to both the producer and consumer, and the development of a method to remove the pesticides before marketing has been eagerly awaited. Thus, the present work was extended out to assess the potency of ozone $\left(\mathrm{O}_{3}\right)$ as a novel engineering science for different contact times as simple wash treatments for removal of chlorpyrifos residues from different sorts of vegeta- bles. The objective of this research was also to study the effect of these wash treatments on vegetable quality parameters such antioxidant capacity (AC), total phenolic contents (TP) and vita$\min \mathrm{C}$ in vegetables.

\section{Materials and methods}

\section{Chemicals}

Analytical grade standard for chlorpyrifos, $(\mathrm{O}, \mathrm{O}-$ diethyl O-3,5,6-trichloro-2-pyridyl phosphorothioate), was obtained from Chemservice, USA, with a purity of $99 \%$ purity, while formulated chlorpyrifos (48 $\mathrm{g}$ a.i./1, EC) was purchased from the local market of Al-Qassim region, KSA. Certified HPLC-grade of ethyl acetate, acetone, methanol, and isooctane were purchased from BDH Company, while the Water spe-20G Column Processor designed vacuum manifold capable of processing up to 20 solid phase extraction (SPE) columns and SPE columns (Waters $\mathrm{spe}^{\mathrm{TM}}, \mathrm{C} 18,500 \mathrm{mg}$ per column) were purchased from Waters, USA. Ultra-pure deionized water of $15 \mathrm{M} \Omega \mathrm{cm}$ resistivity and $\mathrm{pH} 7$ was obtained from a water purification system (PURELAB Option-R, ELGA, UK) and used throughout this study. Glucose, gallic acid and 1, 1-diphenyl-2-picryl hydrazil (DPPH) were obtained from Sigma Co, while, Trolox and Folin-Ciocalteus reagent $(2 \mathrm{~N})$ were obtained from Aldrich and Merck, respectively. All other chemicals used in this study were of the highest grade available.

\section{Vegetables collection and treatment}

Different kinds of vegetables, namely arugula, bell pepper, cabbage, carrot, cucumber, leek, parsley and tomato were obtained from organic farming without the use of pesticides located in Al-Qassim region, KSA. A minimum of 5 samples (the sample size of each commodity ranged from $1-2 \mathrm{~kg}$ ) were collected to give representative sample, put in sterilized polyethylene bags, transported to the laboratory and then stored at $4{ }^{\circ} \mathrm{C}$ until experimentation.

Chlorpyrifos was dissolved in acetone and then mixed with 4 liters of distilled water (DW) to give a concentration of $2 \mathrm{mg} / \mathrm{l}$. Fresh and unblemished pesticide-free vegetables were immersed in pesticide solution for 2 min with gentle rotation by hand. Vegetables with pesticide on the surface were then airdried in static air for about $24 \mathrm{~h}$ at $25 \pm 1{ }^{\circ} \mathrm{C}$.

\section{Ozone generation}

Ozone gas (100 ppm at air flow rate of $2.5 \mathrm{~L} / \mathrm{min}$ with ozone output of $300 \mathrm{mg} / \mathrm{hr}$ ) was produced by a laboratory corona discharge ozone generator (Xetin Ozone Air \& Water purifier, Model XT 301, Xetin Co. Ltd, Taiwan). The ozone generator was warmed up for 15 min before the experiment was conducted. The concentrations of dissolved ozone were measured using a portable ozone detector (DO3, Echo Sensors Inc., USA) in the range between 0 and $10 \mathrm{ppm}$ with the accuracy of 0.01 . The concentration of dissolved ozone was $2 \mathrm{mg} / \mathrm{L}$.

\section{Removal of Residual Pesticide from Vegetables}

Removal of chlorpyrifos from vegetables was studied by using triplicated random vegetable samples treated with the pesticide and divided into the following treatment groups: control (no wash); rinsing in DW having pH 7.0 and ozone dissolved $2 \mathrm{mg} / \mathrm{L}$ of ozone dissolved in DW (OZW) in polypropyl- 
ene reactor for $0,15,30,45$ and $60 \mathrm{~min}$. Solution temperature was kept at either 25 or $35 \pm 1^{\circ} \mathrm{C}$ by water bath. The duration of dissolved ozone levels was controlled via adjusting the duration of bubbling. Excessive gaseous ozone was trapped in $2 \%$ potassium iodide solution.

\section{Sample preparation and solid-phase extraction}

At the end of tested time intervals, vegetables were chopped and a subsample $(10 \mathrm{~g})$ was weighed into $50 \mathrm{ml}$ glass tube and extracted with $20 \mathrm{ml}$ acetone using a homogenizer (Euroturax, IKA Labortechnik Staufen, Germany) at full speed for $5 \mathrm{~min}$. After addition of $10 \mathrm{~g}$ sodium chloride, the homogenate was centrifuged at 3,000 rpm for $5 \mathrm{~min}$ and the supernatant was transferred to a clean graduated cylinder.

SPE was carried out according to Štanbaher \& Zupančič-Kralj, (2003) with slight modification. The columns were conditioned by passing $6 \mathrm{ml}$ of ethyl acetate followed by 6 $\mathrm{ml}$ of methanol and then $8 \mathrm{ml}$ of ultra-pure deionized water. The sorbent was never allowed to dry during the conditioning and sample loading steps. Then the extraction columns were fitted with detachable $70-\mathrm{ml}$ polypropylene reservoirs to contain the diluted sample extract. The extract was transferred to the reservoir, which was partially filled with ultra-pure deionized water and then water was added to the top. Sample loading was performed under vacuum at flow rates of $5 \mathrm{ml} \mathrm{min}{ }^{-1}$. After the passage of the extract, the column was dried by vacuum aspiration under increased vacuum for $30 \mathrm{~min}$. The pesticide was eluted with three 2-ml aliquots of ethyl acetate-acetone at the ratio of 90:10 (v/v). The eluates were collected in $12 \mathrm{ml}$ tubes under gravity flow only. After all the elution solvent had passed through the extraction column, the residual solvent was forcibly removed from the column. The eluate was evaporated to less than $1 \mathrm{ml}$ using a gentle stream of nitrogen and then the solvent was exchanged to isooctane by adding two 2-ml portions of isooctane and evaporated to low volume after each addition. The extract was quantitatively transferred to $2 \mathrm{ml}$ clean vials, completed to $1 \mathrm{ml}$ with isooctane and then analyzed by gas chromatography-mass spectroscopy (GC-MS).

\section{Recovery studies}

The vegetables used in the recovery test were confirmed to be free from chlorpyrifos. For recovery studies, subsamples of known blanks ( $10 \mathrm{~g}$ ) were spiked prior to extraction by the addition of $2 \mathrm{ml}$ of chlorpyrifos standard solution in acetone to give $0.00,0.05,0.25$ or $0.50 \mathrm{mg} / \mathrm{kg}$. They were then prepared according to the proposed procedure as described previously and then absolute recovery and precision (expressed as a relative standard deviation, RSD) were measured by analyzing three samples. The recovery values were 90 - 101, 92 - 95, 96 - 105, 93 - 102, 88 95, 90 - 94, 92 - 99 and 82 - 92\% for bell pepper, tomato, cucumber, carrot, arugula, parsley, cabbage and leek, respectively with precision values ranged from 5 to $15 \%$. The limits of detection (LOD) were calculated from the signal-to-noise ratios obtained by analyzing unspiked samples $(n=10)$; LOD was taken to be the concentrations of pesticide resulting in a signal-to-noise ratio of 3 . The LOD values were $1,0.5,0.8,0.5,1,1.2,0.5$ and 1.5 ppb, respectively with RSD ranged from $5-15 \%$.

\section{Gas chromatography-mass spectrometry (GC-MS)}

Gas chromatography (Model GC 450, Varian Inc., The
Netherlands) with a mass spectrometry (MS 220.41) detector equipped with split/split less injector with electronic pressure control was employed. A fused silica CP-Sil 8 CB-LB/MS capillary column (30 m x $0.25 \mathrm{~mm}$ i.d) was used in combination with the following oven temperature program: initial temperature 100 ${ }^{\circ} \mathrm{C}$, held for $1 \mathrm{~min}, 5{ }^{\circ} \mathrm{C} / \mathrm{min}$ ramp to $260{ }^{\circ} \mathrm{C}$ held for $11 \mathrm{~min}$. The injector temperature was $280{ }^{\circ} \mathrm{C}$ and mass range from $50-650$ amu. The carrier gas (helium, $99.999 \%$ ) flow rate was set to a constant head pressure of $200 \mathrm{kPa}$ at a flow rate of $1.2 \mathrm{ml} / \mathrm{min}$ with a split ratio of 1: $20 \mathrm{~min}$. The mass spectrometer was operated in electron ionization mode with a transfer line temperature of $280{ }^{\circ} \mathrm{C}$, manifold temperature $40{ }^{\circ} \mathrm{C}$, ion trap temperature $200{ }^{\circ} \mathrm{C}$, ion source $230{ }^{\circ} \mathrm{C}$ and selected ion monitoring (SIM) mode. The ion energy for electron impact (EI) was kept at 70 eV. MS Workstation version 6.9.1 was used for data acquisition. For positive identification, retention time (Rt) and the presence of five fragment ions ( $\mathrm{z} / \mathrm{m}$ ions: $352,314,258,197$ and 97$)$ were considered.

Calibration was achieved by preparing matrix calibration standards from the extracts of blank samples in order to compensate for matrix effect. Analytes were quantified by using a 3-point calibration with those matrices matched calibration standards corresponding to the spiked concentration. Figures 1 and 2 represent the GC-MS chromatogram corresponding to standard chlorpyrifos (1 ppm) and tomatoes immersed in $2 \mathrm{mg} /$ $\mathrm{kg}$ chlorpyrifos and immersed in $\mathrm{O}_{3}$, respectively.

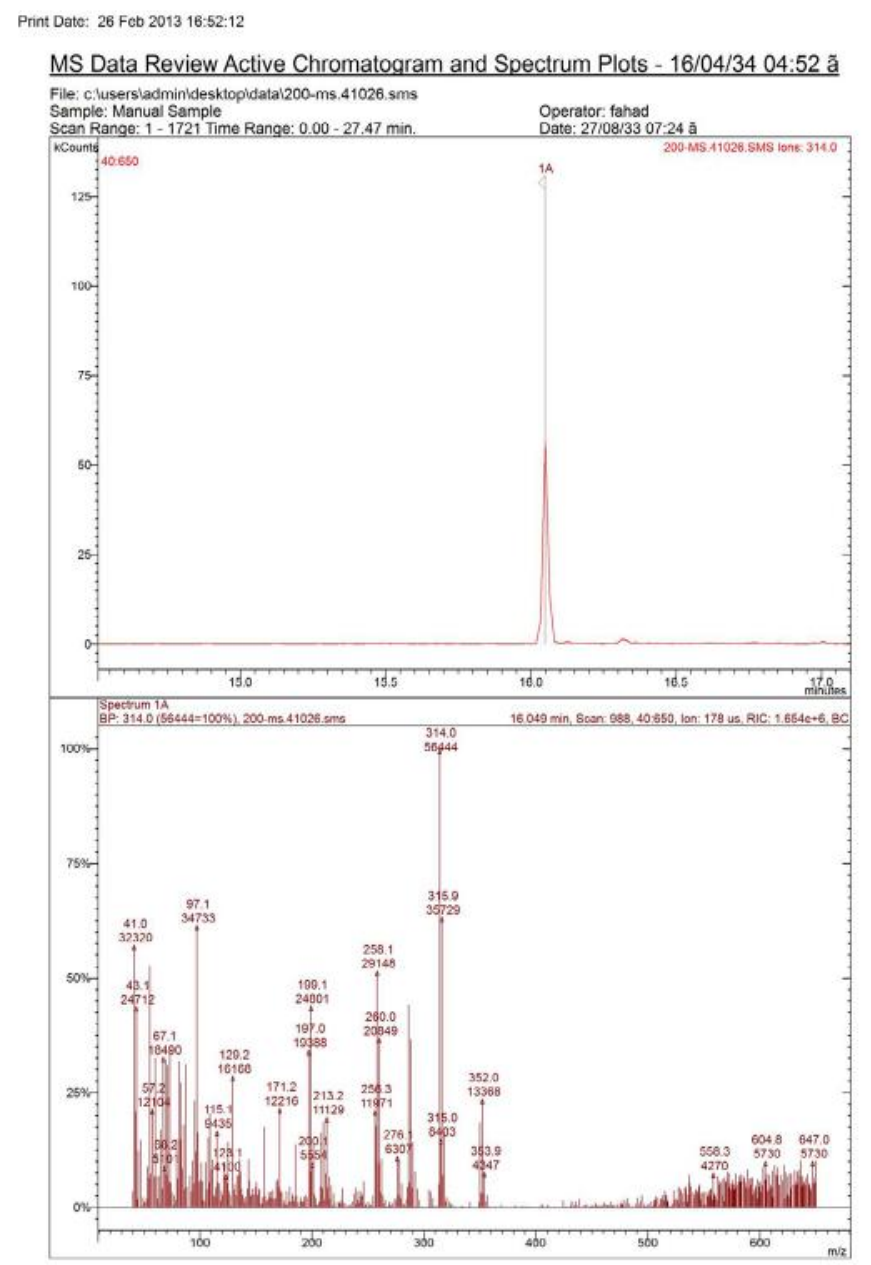

Figure 1: GC-MS chromatogram corresponding to standard chlorpyrifos $(1 \mathrm{ppm})$. 


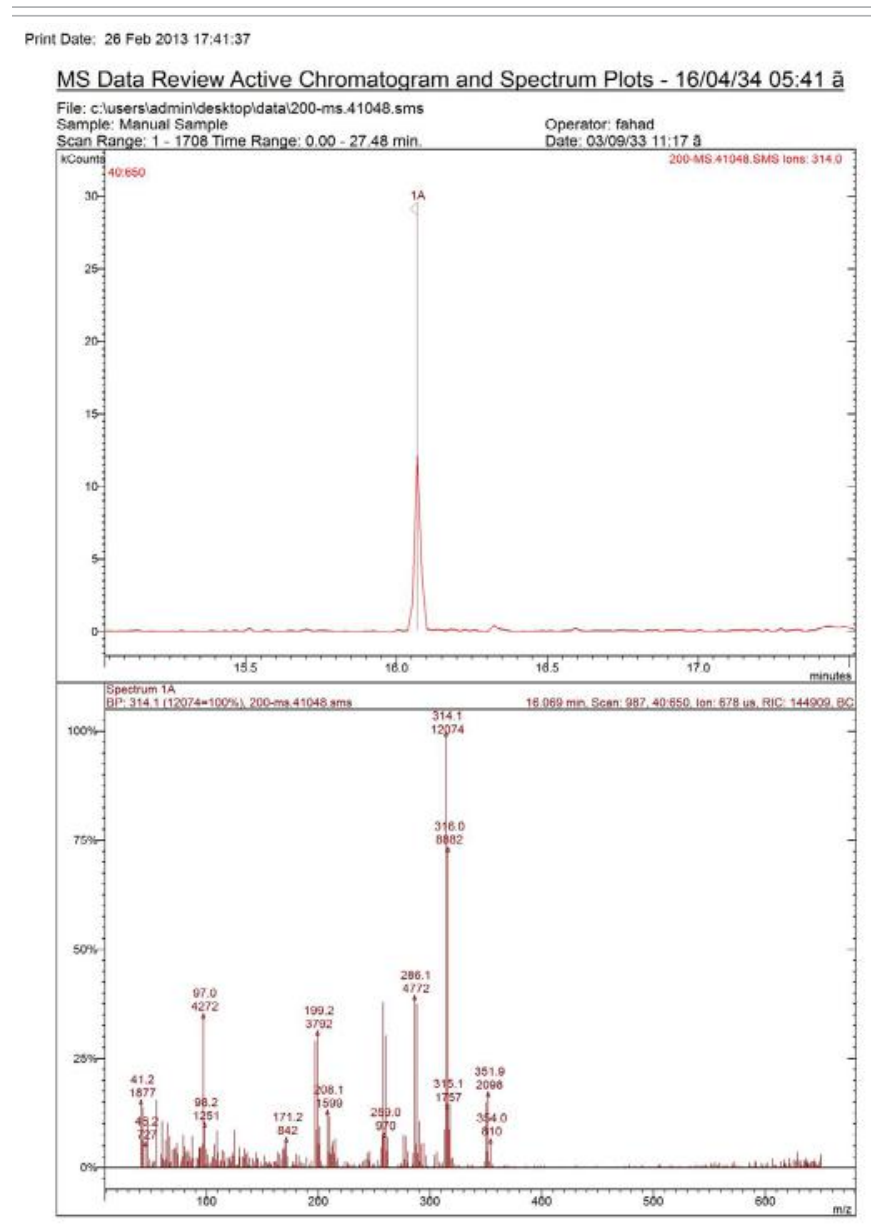

Figure 2: GC-MS chromatogram corresponding to tomatoes immersed in $2 \mathrm{mg} / \mathrm{kg}$ chlropyrifos and immersed in $\mathrm{O}_{3}$.

\section{Effect of treatment on vegetable quality}

The level of vitamin $C$ in vegetables was measured according to the method of Klein and Perry (1982) using 2,6-Dichlorophenolindophenol (DCPIP) as an indicator at $515 \mathrm{~nm}$. Vegetable sample was homogenized with blender at full speed for $2 \mathrm{~min}$, weighed (1g) into $50 \mathrm{ml}$ Teflon centrifuge tube containing $20 \mathrm{ml}$ of $2 \%$ of oxalic acid, vigorously shacked for $1 \mathrm{~h}$ and centrifuged at 3,000 rpm for $10 \mathrm{~min}$. Supernatant was used to measure the level of vitamin $\mathrm{C}$ and the results were expressed as $\mathrm{mg}$ vitamin $\mathrm{C} / 100 \mathrm{~g}$ of fresh weight.

\section{Extraction of total phenolics}

One gram of sample was put into $50 \mathrm{ml}$ Teflon centrifuge tube and extracted with $25 \mathrm{ml} 80 \%$ ethanol using the homogenizer at full speed for $2 \mathrm{~min}$. The extract was centrifuged at 4,000 rpm for $10 \mathrm{~min}$ and the supernatant was used to measure total phenolics (TP) and antioxidant capacity (AC).

\section{Total phenolics}

TP was determined according the method of Singleton and Rossi (1965) using the Folin-Ciocalteus reagent. In brief, $0.1 \mathrm{ml}$ of extract was added to $7.9 \mathrm{ml}$ of distilled water, $0.5 \mathrm{ml}$ of Folin-Ciocalteus reagent, $1.5 \mathrm{ml}$ of sodium carbonate solution (200 g/l) and then mixed vigorously. The mixture was allowed to stand for $1 \mathrm{~h}$ at the room temperature and then the absorbency was measured at a wavelength of $765 \mathrm{~nm}$. Gallic acid (GAE) was used as a standard and the results were expressed as mg equivalents GAE/ $100 \mathrm{~g}$ of fresh weight.

\section{Antioxidant capacity}

$\mathrm{AC}$ or free radical scavenging activity was determined $^{[28]}$ using 1,1-diphenyl-2-picryl-hydrazil (DPPH) reagent. In brief, $1.5 \mathrm{ml}$ of freshly prepared methanolic DPPH solution $(0.02 \mathrm{mg} / \mathrm{ml})$ was added to $0.75 \mathrm{ml}$ of $80 \%$ ethanol extract and then stirred. The decolourizing process was recorded after 5 min of reaction at a wavelength of $517 \mathrm{~nm}$ and compared with a blank control using the Spectrophotometer. The DPPH radical scavenging activity of the extracts was measured using the Trolox standard curve. Results were expressed as $\mu$ mol Trolox equivalent (TE) antioxidant capacity/100 g of fresh weight.

\section{Statistical analysis}

Treatments were done in triplicate for each time. Data were calculated as mean \pm SD analyzed using ANOVA. A probability of 0.05 or less was considered significant. The statistical package of the Costat Program (1986) was used for all chemo metric calculations.

\section{Results and discussion}

\section{Removing of chlorpyrifos by wash treatments}

Postharvest treatments, such as the postharvest water wash and scrub that have been traditionally used to get rid of rubble and dirt, have been proven to reduce pesticide residues (El-Hadidi, 1993). The use of postharvest ozone dips has also demonstrated potential as an effective postharvest treatment in the reduction of pesticide residues on apple fruits. The use of ozonated water dips has similar potential as an alternative postharvest treatment method to remove pesticides from date fruits.

In the present study, the effects of DW and OZW wash treatments at 25 and $35^{\circ} \mathrm{C}$ for different dipping times on chlorpyrifos removal from different kinds of vegetables were investigated (Table 1). The initial levels of residual chlorpyrifos varied with the kind of vegetables, where arugula had the highest level followed by parsley, leek, tomato, carrot, cucumber, cabbage, and then bell pepper. The levels of natural waxing and properties of vegetables impact the quantity of pesticide retained by vegetables $^{[25]}$, where non-polar pesticides are tenaciously held in the waxy layer of peel of fruits and vegetables ${ }^{[3]}$.

In the present study, it was observed that the removal pesticide percentages by DW washing for 60 min meaningfully changed with the washing temperature increase. The percentages of chlorpyrifos removal ranged from 18 - 42 and 48 - $63 \%$ at 25 and $35^{\circ} \mathrm{C}$, respectively. As a result, the results of this study demonstrated that the removal of the pesticide from the vegetables by washing with DW depended on the type of vegetables. Also, it was found that, the amount of chlorpyrifos residues was significantly decreased exponentially as the contact time increased in vegetables treated with ozonated water at $25{ }^{\circ} \mathrm{C}$; however, at $35^{\circ} \mathrm{C}$ the percentages of chlorpyrifos removal did not depend on the contact of time for all the tested vegetables except arugula. Compared with the control (no wash treatment), both DW wash and OZW treatments significantly $(\mathrm{p}<0.05)$ reduced the tested pesticide residual levels on vegetable. However, in most cases when vegetables washed with OZW the residual levels reduced significantly $(\mathrm{p}<0.05)$ compared with the DW treatment. When vegetables washed with DW for 60 min either at 25 or $35^{\circ} \mathrm{C}$, the highest and lowest percentages of chlorpyrifos removal (42 and 18\%) was recorded for cabbage and parsley 
when the temperature was $25^{\circ} \mathrm{C}$, while the highest and lowest percentages of chlorpyrifos removal (63 and 49\%) was recorded for parsley and bell pepper, respectively.

Table 1: Levels $(\mu \mathrm{g} / \mathrm{g})$ and removal percentages (in parenthesis) of chlorpyrifos from different kinds of vegetables after distilled water and ozone wash treatment.

\begin{tabular}{|c|c|c|c|c|c|c|c|c|c|c|c|}
\hline \multirow{3}{*}{ Commodity } & \multirow{3}{*}{$\begin{array}{l}\text { Without } \\
\text { washing }\end{array}$} & \multicolumn{5}{|c|}{$25^{\circ} \mathrm{C}$} & \multicolumn{5}{|c|}{$35^{\circ} \mathrm{C}$} \\
\hline & & \multicolumn{5}{|c|}{ Contact time (min) } & \multicolumn{5}{|c|}{ Contact time (min) } \\
\hline & & $\mathrm{DW}^{1}$ & 15 & 30 & 45 & 60 & $\mathrm{DW}^{1}$ & 15 & 30 & 45 & 60 \\
\hline Bell pepper & $\begin{array}{l}22.18 \pm \\
1.11 \mathrm{aD}\end{array}$ & $\begin{array}{l}13.73 \pm \\
1.30 \mathrm{dC} \\
(32)\end{array}$ & $\begin{array}{l}15.54 \pm \\
0.22 \mathrm{cC} \\
(30)\end{array}$ & $\begin{array}{l}10.20 \pm \\
3.63 \mathrm{cB} \\
(54)\end{array}$ & $\begin{array}{l}8.46 \pm \\
2.29 \mathrm{cB} \\
(62)\end{array}$ & $\begin{array}{l}3.86 \pm \\
1.13 \mathrm{bA} \\
(83)\end{array}$ & $\begin{array}{l}10.87 \pm \\
1.31 \mathrm{fBF} \\
(49)\end{array}$ & $\begin{array}{l}5.63 \pm \\
1.56 \mathrm{bAB} \\
(75)\end{array}$ & $\begin{array}{l}3.47 \pm \\
0.16 \mathrm{bA} \\
(84)\end{array}$ & $\begin{array}{l}7.72 \pm \\
0.10 \mathrm{dfD} \\
(65)\end{array}$ & $\begin{array}{l}11.18 \pm \\
0.89 \mathrm{cF} \\
(50)\end{array}$ \\
\hline Tomato & $\begin{array}{l}37.73 \pm \\
1.63 \mathrm{dD}\end{array}$ & $\begin{array}{l}22.27 \pm \\
1.55 \mathrm{cB} \\
(41)\end{array}$ & $\begin{array}{l}3.31 \pm \\
0.99 \mathrm{aA} \\
(91)\end{array}$ & $\begin{array}{l}2.02 \pm \\
0.96 \mathrm{aA} \\
(95)\end{array}$ & $\begin{array}{l}1.80 \pm \\
0.97 \mathrm{aA} \\
(95)\end{array}$ & $\begin{array}{l}1.33 \pm \\
1.89 \mathrm{aA} \\
(97) \\
\end{array}$ & $\begin{array}{l}17.01 \pm \\
0.88 \mathrm{~dB} \\
(55)\end{array}$ & $\begin{array}{l}3.58 \pm \\
1.29 \mathrm{abA} \\
(91)\end{array}$ & $\begin{array}{l}1.91 \pm \\
1.61 \mathrm{aA} \\
(95)\end{array}$ & $\begin{array}{l}2.31 \pm \\
0.34 \mathrm{aA} \\
(94)\end{array}$ & $\begin{array}{l}4.02 \pm \\
0.32 \mathrm{aA} \\
(89)\end{array}$ \\
\hline Cucumber & $\begin{array}{l}28.55 \pm \\
1.30 \mathrm{bC}\end{array}$ & $\begin{array}{l}21.13 \pm \\
0.50 \mathrm{cC} \\
(26)\end{array}$ & $\begin{array}{l}5.65 \pm \\
1.26 \mathrm{bB} \\
(80)\end{array}$ & $\begin{array}{l}3.18 \pm \\
0.49 \mathrm{aAB} \\
(89)\end{array}$ & $\begin{array}{l}2.48 \pm \\
1.25 \mathrm{aA} \\
(91)\end{array}$ & $\begin{array}{l}2.40 \pm \\
1.54 \mathrm{aA} \\
(92)\end{array}$ & $\begin{array}{l}13.70 \pm \\
0.11 \mathrm{eB} \\
(48)\end{array}$ & $\begin{array}{l}6.14 \pm \\
0.56 \mathrm{bA} \\
(78)\end{array}$ & $\begin{array}{l}4.73 \pm \\
1.19 \mathrm{bA} \\
(83)\end{array}$ & $\begin{array}{l}4.83 \pm \\
0.81 \mathrm{bcA} \\
(83)\end{array}$ & $\begin{array}{l}4.85 \pm \\
0.07 \mathrm{aA} \\
(83)\end{array}$ \\
\hline Carrot & $\begin{array}{l}32.09 \pm \\
0.88 \mathrm{cD}\end{array}$ & $\begin{array}{l}20.81 \pm \\
1.05 \mathrm{cB} \\
(35)\end{array}$ & $\begin{array}{l}2.43 \pm \\
0.48 \mathrm{aA} \\
(92)\end{array}$ & $\begin{array}{l}2.13 \pm \\
0.27 \mathrm{aA} \\
(93)\end{array}$ & $\begin{array}{l}1.78 \pm \\
0.49 \mathrm{aA} \\
(94)\end{array}$ & $\begin{array}{l}1.57 \pm \\
0.6 \mathrm{aA} \\
(95) \\
\end{array}$ & $\begin{array}{l}16.22 \pm \\
1.22 \mathrm{~dB} \\
(51)\end{array}$ & $\begin{array}{l}1.62 \pm \\
0.03 \mathrm{aA} \\
(95)\end{array}$ & $\begin{array}{l}3.60 \pm \\
0.10 \mathrm{abA} \\
(89)\end{array}$ & $\begin{array}{l}3.48 \pm \\
1.09 \mathrm{abA} \\
(89)\end{array}$ & $\begin{array}{l}3.50 \pm \\
0.41 \mathrm{aA} \\
(89)\end{array}$ \\
\hline Arugula & $\begin{array}{l}112.21 \pm \\
2.11 \mathrm{gF}\end{array}$ & $\begin{array}{l}68.60 \pm \\
0.76 \mathrm{aC} \\
(39)\end{array}$ & $\begin{array}{l}14.32 \pm \\
0.32 \mathrm{cB} \\
(87)\end{array}$ & $\begin{array}{l}5.25 \pm \\
1.64 \mathrm{bA} \\
(95)\end{array}$ & \begin{tabular}{|l}
$5.18 \pm$ \\
$0.51 \mathrm{bA}$ \\
$(95)$ \\
\end{tabular} & \begin{tabular}{|l}
$3.02 \pm$ \\
$2.1 \mathrm{aA}$ \\
$(97)$ \\
\end{tabular} & $\begin{array}{l}58.35 \pm \\
2.04 \mathrm{aE} \\
(52)\end{array}$ & $\begin{array}{l}17.77 \pm \\
0.66 \mathrm{C} \\
(84)\end{array}$ & $\begin{array}{l}12.64 \pm \\
0.27 \mathrm{cC} \\
(89)\end{array}$ & $\begin{array}{l}8.26 \pm \\
0.06 \mathrm{cdfB} \\
(93)\end{array}$ & $\begin{array}{l}4.87 \pm \\
0.17 \mathrm{aA} \\
(96)\end{array}$ \\
\hline Parsley & $\begin{array}{l}85.72 \pm \\
2.54 \mathrm{fC}\end{array}$ & $\begin{array}{l}70.49 \pm \\
0.78 \mathrm{aB} \\
(18)\end{array}$ & $\begin{array}{l}3.89 \pm \\
0.90 \mathrm{bA} \\
(95)\end{array}$ & $\begin{array}{l}2.48 \pm \\
0.13 \mathrm{aA} \\
(97) \\
\end{array}$ & $\begin{array}{l}2.46 \pm \\
0.06 \mathrm{aA} \\
(97) \\
\end{array}$ & $\begin{array}{l}2.39 \pm \\
0.09 \mathrm{abA} \\
(97) \\
\end{array}$ & $\begin{array}{l}31.31 \pm \\
0.69 \mathrm{bB} \\
(63)\end{array}$ & $\begin{array}{l}5.07 \pm \\
0.53 \mathrm{bA} \\
(94)\end{array}$ & $\begin{array}{l}8.02 \pm \\
0.12 \mathrm{cA} \\
(91)\end{array}$ & $\begin{array}{l}6.17 \pm \\
0.0 \mathrm{cdA} \\
(93)\end{array}$ & $\begin{array}{l}7.83 \pm \\
1.41 \mathrm{bA} \\
(91)\end{array}$ \\
\hline Cabbage & $\begin{array}{l}24.60 \pm \\
1.76 \mathrm{aD}\end{array}$ & $\begin{array}{l}14.18 \pm \\
0.13 \mathrm{dC} \\
(42)\end{array}$ & $\begin{array}{l}8.74 \pm \\
1.93 \mathrm{bA} \\
(64)\end{array}$ & $\begin{array}{l}6.18 \pm \\
1.86 \mathrm{bA} \\
(75)\end{array}$ & $\begin{array}{l}\text { ND } \\
(100)\end{array}$ & $\begin{array}{l}\text { ND } \\
(100)\end{array}$ & $\begin{array}{l}11.08 \pm \\
0.83 \mathrm{f} \\
(55)\end{array}$ & $\begin{array}{l}\text { ND } \\
(100)\end{array}$ & $\begin{array}{l}\text { ND } \\
(100)\end{array}$ & $\begin{array}{l}\text { ND } \\
(100)\end{array}$ & $\begin{array}{l}\text { ND } \\
(100)\end{array}$ \\
\hline Leek & $\begin{array}{l}72.67 \pm \\
2.33 \mathrm{eE}\end{array}$ & $\begin{array}{l}44.95 \pm \\
0.31 \mathrm{bC} \\
(38)\end{array}$ & $\begin{array}{l}7.18 \pm \\
2.36 \mathrm{abB} \\
(90)\end{array}$ & $\begin{array}{l}6.01 \pm \\
10.25 \mathrm{bB} \\
(91)\end{array}$ & $\begin{array}{l}3.82 \pm \\
0.58 \mathrm{aA} \\
(95)\end{array}$ & $\begin{array}{l}2.15 \pm \\
0.67 \mathrm{aA} \\
(97)\end{array}$ & $\begin{array}{l}28.12 \pm \\
1.05 \mathrm{cD} \\
(61)\end{array}$ & $\begin{array}{l}3.60 \pm \\
1.22 \mathrm{abAB} \\
(95)\end{array}$ & $\begin{array}{l}2.94 \pm \\
1.28 \mathrm{aA} \\
(96)\end{array}$ & $\begin{array}{l}5.20 \pm \\
0.98 \mathrm{bB} \\
(93)\end{array}$ & $\begin{array}{l}8.75 \pm \\
0.49 \mathrm{bC} \\
(88)\end{array}$ \\
\hline
\end{tabular}

${ }^{\mathrm{v}}$ vegetable washed with DW for $60 \mathrm{~min}$.

Each value is the mean \pm S.D of three replicates.

Means having different small letters in column or capital letters in row are significantly different $(\mathrm{P}<0.05)$.

ND means non detected.

Data in Table (1) showed that when vegetables contaminated with $2 \mathrm{mg} / \mathrm{l}$ of chlorpyrifos and then washed with OZW for $15-60 \mathrm{~min}$ as contact times at $25{ }^{\circ} \mathrm{C}$, the percentages of removal were time-dependent and ranged from 30 - 83, 91 - 97, $80-92,92-95,87-97,95-97,64-100$ and $90-97 \%$ for bell pepper, tomato, cucumber, carrot, arugula, parsley, cabbage and leek, respectively. In case of vegetables contaminated with $2 \mathrm{mg} / \mathrm{l}$ of chlorpyrifos and then washed with OZW at $35^{\circ} \mathrm{C}$, the highest percentages of chlorpyrifos removal were recorded after $15 \mathrm{~min}$ for cabbage, parsley and carrot, $30 \mathrm{~min}$ for bell pepper, tomato, carrot and leek and $60 \mathrm{~min}$ for arugula as a contact time. No detectable amounts of chlorpyrifos were found in cabbage that was immersed in ozonated water for 45 and 60 min at a temperature of $25{ }^{\circ} \mathrm{C}$ and for all the tested time intervals at 35 ${ }^{\circ} \mathrm{C}$. As the contact time increased and the temperature of OZW $35^{\circ} \mathrm{C}$, ozone treatments did not improve degradation efficiency, showing that ozone concentrations were enough for the oxidization $^{[29]}$. Although the high temperature benefits the chemical reaction between oxidants and substrates, it decreases the partial pressure of dissolved ozone in aqueous condition.

In many cases the increase in temperature of OZW from 25 to $35^{\circ} \mathrm{C}$ did not increase the removal percentages of chlorpyrifos from vegetables. Increasing of applied ozone dosage was not significantly effect on the removal percentages of chlorpyrifos ethyl, tetradifon and chlorothalonil from the lemon, orange and grapefruit matrices, whereas increasing of ozonation temperature caused a negative effect on the removal percentages of pesticides (Kusvuran et al., 2012) and did not significantly (P $<0.05$ ) increase the rate of degradation of azinphosmethyl by ozone $^{[27]}$. (Ong et al., 1996) This may be due to the solubility of ozone in water is inversely proportional to temperature ${ }^{[25]}$. However, higher temperature enhanced the efficacy in the removal of methyl-parathion, parathion, diazinon and cypermethrin on vegetable surface (Brassica rapa) ${ }^{[25]}$.

The results from the present study were in agreement with those reported by ${ }^{[8,25]}$ who found that tap water and ozonated water treatments significantly $(p<0.05)$ reduced pesticide the residual levels on vegetable, compared with the no wash treatment ${ }^{[8,25]}$. However, OZW wash further reduced the residual levels significantly $(p<0.05)$, compared with the tap water treatment. Azinphos-methyl, captan and formetanate hydrochloride in solution and on fresh and processed apples decreased by 50 - $100 \%$ with ozone treatment ${ }^{[27]}$, mancozeb residues decreased by $56-97 \%$ with ozone treatment at 1 and $3 \mathrm{ppm}$ of ozone ${ }^{[30]}$. These differences could be attributed to a great variability in the conditions of the application, such as the feeding gas technique, the method used for ozone generation and application, the ozone concentration, and, above all, the exposure interval to the $\operatorname{gas}^{[31]}$. 
The quantity of pesticide being retained by vegetable highly depends on the levels of ozone and temperature ${ }^{[25]}$. From the results obtained in this research work and assuming the criterion that a treatment is efficient in degrading pesticides if a removal percentage of above $70 \%$ is obtained ${ }^{[26]}$, in the most cases OZW at $2 \mathrm{mg} / 1$ removed more than $70 \%$. The present study revealed that removing of chlorpyrifos depends on the contact times when the temperature was $25^{\circ} \mathrm{C}$. Nevertheless, the increased in temperatures did not significantly $(\mathrm{P}<0.05)$ increase the rate of degradation of azinphosmethyl by ozone ${ }^{[27]}$.

$\mathrm{O}_{3}$ has a powerful oxidant having electrochemical oxidation potential of $2.0 \mathrm{~V}$, and therefore, can modify the chemical structure of the selected pesticides creating derived by-products. If these by-products are more toxic than the parent pesticide, such washing treatments should not be utilized to reduce pesticide residue levels in vegetables. It is well recognized that some organo phosphorus pesticides containing $\mathrm{P}=\mathrm{S}$ bonds (actually organothiophosphorus pesticides) such as chlorpyrifos react with oxidative reagents producing its respective oxygen analogs (e.g. chlorpyrifos-oxon), which are more potent as mammalian acetyl cholinesterase inhibitors than the parent forms (Amdur et al. 1991). The possible formation of toxic by-products by either $\mathrm{O}_{3}$ was investigated by gas chromatography mass spectrometry (GC-MS) in SCAN mode by monitoring $\mathrm{m} / \mathrm{z}$ ions: 109 , 197, 242, 270, 298 and 335 for chlorpyrifos-oxon. In the GCMS analysis, chlorpyrifos appeared as a sharp and only a single peak at a retention time of 16.14 min corresponding to chlorpyrifos was observed in the GC-MS chromatogram and there is no intermediate or dead-end product detected using the analytical method described in the present study (Figure 2). Products of chlorpyrifos degradation include 3, 5, 6-trichloro-2-pyridinol which subsequently breaks down to organ chlorine compounds and carbon dioxide (The Royal Society of Chemistry 1988). The present results are in accordance with many investigators who found that no toxic by-products such as chlorpyrifos-oxon, amitraz and dicofol were detected in date fruits (Osman et al. 2014; Osman 2015), chlorpyrifos-oxon, malaoxon, methidaoxon and methyl paraoxon in the extracts of the washed samples for the washing-time and low concentrations of sodium hypochlorite, $\mathrm{KMnO}_{4}$ and $\mathrm{H}_{2} \mathrm{O}_{2}{ }^{[32]}$ (Pugliese et al. 2004) ethylenethiourea residue at $1 \mathrm{ppm}$ of spiked mancozeb after both 3 and $30 \mathrm{~min}$ of ozone treatment (Hwang et al. 2001). On the other hand, at high concentrations of sodium hypochlorite, $\mathrm{KMnO}_{4}$ and $\mathrm{H}_{2} \mathrm{O}_{2}$, oxon from the organ phosphorus pesticides were identified ${ }^{[32]}$. $\mathrm{O}_{3}$ selectively reacts with compounds containing heteroatoms such as $\mathrm{S}, \mathrm{N}, \mathrm{O}$, and $\mathrm{Cl}$ via two different pathways, namely direct molecular and indirect radical chain-type reactions ${ }^{[33]}$. The reactivity of compounds with ozone varies largely due to their diverse structural feature ${ }^{[8]}$. Thus, pesticides, which usually have some heteroatoms on the molecules, are often expected to be destroyed by ozonation ${ }^{[34]}$. So it is recommended to use $\mathrm{O}_{3}$ as non-toxic washing treatment to reduce such residues in vegetables.

\section{Effect of wash treatments on vegetables quality parameters}

The effect of ozone wash treatments on quality parameters of vegetables is of interest since the wash treatment may be performed by vegetable' producers and consumers. Because vegetables are rich in antioxidant compounds, therefore, its consumption is considered to be one of the main factors of a healthy lifestyle ${ }^{[6,7]}$. Unfortunately, few studies dealt with the effect of ozone wash treatments on vegetable quality parameters ${ }^{[35-45]}$. Thus, research is needed to investigate the effect of current wash treatments on $\mathrm{AC}, \mathrm{TP}$ and vitamin $\mathrm{C}$, and ultimately devise ideal conditions of wash treatments suitable for vegetables.

Variations in the levels of AC (Table 2), TP (Table 3) and vitamin $C$ (Table 4) contents were observed between the tested varieties, however tomatoes, arugula and parsley tended to have the highest values of AC, TP and vitamin C, respectively. Also, the present study revealed that in most cases the levels of AC, TP and vitamin $\mathrm{C}$ of the tested vegetables did not show significant variations either throughout the dipping times or the tested temperatures. The present study is in parallel to that found in tomatoes where $\mathrm{O}_{3}$-enriched atmosphere (concentration up to $1 \mu \mathrm{mol} \mathrm{mol}^{-1}$ ) did not attain statistical significance change in AC and $\mathrm{TP}^{[35]}$. In addition, the low ozone concentration did not affect organic acids, soluble sugars, lycopene and other micronutrients of vegetables and fruits ${ }^{[35]}$. (Ibanoglu, 2002; Mendez et al., 2003) or colour and pulling strength of persimmon leaves (Ikeura et al., 2013). Moreover, ozone is able to preserve the polyphenol and anthocyanin contents in grape and keeps the pectin methyl esterase and polygalacturonase activities ${ }^{[36]}$ because it is changed into oxygen by autolysis (Li and Tsuge, 2006); therefore, it leaves no residues on treated commodities and this indicates that the penetration of ozone into the vegetable is unlikely. However, many reports have reported that quality of fruits and vegetables is greatly affected by post-harvest treatments ${ }^{[37]}$ by affecting the nutritional and sensory quality of the product ${ }^{[38]}$. Plant pigment is bleached after treatment with ozonated water ${ }^{[8]}$ (Badani et al., 1996; Klaiber et al., 2004; Lewis et al., 1996) and enhances the synthesis of resveratrol and of other bioactive phenolics in grape ${ }^{[39]}$. The long-term ozone treatment greatly reduces the polyphenol content in grapes ${ }^{[36]}$ (Botondi et al., 2015).

It is established that the presence of $\mathrm{AC}$ in the plant is due mainly to the presence of water-soluble compounds with potent free radical-scavenging effects, including phenolic compounds (mainly cinnamic acids) and flavonoids (flavones, flavonols and flavanones) ${ }^{[40-45]}$. Significant correlation between AC and TP in date palm fruits has been established by many investigators ${ }^{[45,46]}$ confirming that these compounds play important role in antioxidant activities ${ }^{[4]]}$.

This result indicated that using $\mathrm{O}_{3}$ for pesticide removal did not produce any undesirable effect on AC, TP and vitamin $\mathrm{C}$ of the tested vegetables. The present investigations are in parallel with ${ }^{[48-57]}$ Selma et al. (2008) who illustrated that there was no evidence of damage in melons treated with hot water, $\mathrm{O}_{3}$ or their combination and they maintained initial texture and aroma. However, due to its strong oxidizing activity, $\mathrm{O}_{3}$ may also cause physiological injury to fresh-cut produce ${ }^{[48]}$. Therefore, the possible negative impact of $\mathrm{O}_{3}$ treatment on fruits sensory quality warrants further study ${ }^{[58-70]}$. In some cases ozone may promote oxidation degradation of chemical constituents present in the grains, discoloration or development (Mendez et al. (2003) and alter the amino acid and fatty acid profile in aqueous solutions (Richard and Brener, 1984) by oxidizing the sulfhydryl group ($\mathrm{SH})$ of amino acids and oxidation of polyunsaturated fatty acids to peroxides ${ }^{[23]}$ (Guzel-Seydim et al., 2004) thus influencing the nutritional and metabolic value of $\operatorname{grain}^{[71-90]}$. 
Ozone as a Safety Post-Harvest Treatment for Chlorpyrifos

Table 2: Effect of temperatures of distilled and ozone water treatments on the antioxidant capacity (AC) of the tested vegetables treated with chlorpyrifos.

\begin{tabular}{|l|c|c|c|c|c|}
\hline & & \multicolumn{2}{|c|}{$\mathbf{2 5}^{\mathbf{}} \mathbf{C}$} & \multicolumn{2}{c|}{$\mathbf{3 5}^{\mathbf{}} \mathbf{C}$} \\
\hline Commidity & Without washing & $\mathbf{D W}^{\mathbf{1}}$ & $\mathbf{O Z W}^{\mathbf{1}}$ & $\mathbf{D W}^{\mathbf{1}}$ & $\mathbf{O Z W}^{\mathbf{1}}$ \\
\hline Bell pepper & $13.55 \pm 1.21 \mathrm{bA}$ & $13.18 \pm 1.55 \mathrm{bA}$ & $11.45 \pm 1.72 \mathrm{bA}$ & $12.40 \pm 1.67 \mathrm{bA}$ & $11.58 \pm 1.73 \mathrm{aA}$ \\
\hline Tomato & $148.66 \pm 4.65 \mathrm{eA}$ & $147.98 \pm 7.22 \mathrm{eA}$ & $149.64 \pm 2.77 \mathrm{eA}$ & $151.90 \pm 7.97 \mathrm{eA}$ & $148.27 \pm 5.93 \mathrm{eA}$ \\
\hline Cucumber & $36.41 \pm 2.88 \mathrm{aA}$ & $35.50 \pm 2.83 \mathrm{dA}$ & $39.35 \pm 2.45 \mathrm{~dB}$ & $38.23 \pm 1.53 \mathrm{~dB}$ & $40.88 \pm 2.30 \mathrm{~dB}$ \\
\hline Carrot & $5.98 \pm 0.65 \mathrm{aA}$ & $5.88 \pm 0.22 \mathrm{aA}$ & $5.63 \pm 0.17 \mathrm{aA}$ & $6.38 \pm 0.77 \mathrm{aA}$ & $6.10 \pm 0.42 \mathrm{aA}$ \\
\hline Arugula & $17.06 \pm 1.87 \mathrm{cA}$ & $17.28 \pm 1.76 \mathrm{bA}$ & $14.23 \pm 2.18 \mathrm{bB}$ & $14.90 \pm 1.55 \mathrm{bB}$ & $13.60 \pm 2.09 \mathrm{bB}$ \\
\hline Parsley & $12.26 \pm 2.88 \mathrm{bA}$ & $12.90 \pm 2.72 \mathrm{bA}$ & $10.68 \pm 0.81 \mathrm{bA}$ & $12.95 \pm 2.40 \mathrm{bA}$ & $10.88 \pm 0.62 \mathrm{bA}$ \\
\hline Cabbage & $4.54 \pm 0.51 \mathrm{aA}$ & $4.73 \pm 0.43 \mathrm{aA}$ & $4.28 \pm 0.32 \mathrm{aA}$ & $4.70 \pm 0.37 \mathrm{aA}$ & $4.13 \pm 0.25 \mathrm{aA}$ \\
\hline Leek & $20.33 \pm 1.21 \mathrm{dA}$ & $21.85 \pm 0.99 \mathrm{cA}$ & $22.10 \pm 1.10 \mathrm{cA}$ & $20.40 \pm 1.23 \mathrm{cA}$ & $20.85 \pm 1.28 \mathrm{cA}$ \\
\hline
\end{tabular}

${ }^{1}$ vegetable washed with DW or ODW for 60 min, respectively.

Data are expressed as $\mu \mathrm{mol}$ Trolox equivalent (TE) antioxidant capacity $/ 100 \mathrm{~g}$ fresh weight of vegetable.

Each value is the mea \pm S.D of three replicates.

Means having different small letters in column or capital letters in row are significantly different $(\mathrm{P}<0.05)$.

Table 3: Effect of temperatures of distilled and ozone water treatments on the on total phenolics of the tested vegetables treated with chlorpyrifos.

\begin{tabular}{|l|c|c|c|c|c|}
\hline & & $\mathbf{2 5}^{\mathbf{}} \mathbf{C}$ & \multicolumn{2}{c|}{$\mathbf{3 5}^{\mathbf{}} \mathbf{C}$} \\
\hline Commidity & Without washing & $\mathbf{D W}^{\mathbf{1}}$ & $\mathbf{O Z W}^{\mathbf{1}}$ & $\mathbf{D W}^{\mathbf{1}}$ & $\mathbf{O Z W}^{\mathbf{1}}$ \\
\hline Bell pepper & $70.12 \pm 3.50 \mathrm{dA}$ & $70.03 \pm 3.07 \mathrm{dA}$ & $71.65 \pm 3.44 \mathrm{dA}$ & $71.85 \pm 1.75 \mathrm{cA}$ & $70.93 \pm 2.65 \mathrm{cA}$ \\
\hline Tomato & $65.21 \pm 3.98 \mathrm{cA}$ & $66.55 \pm 1.65 \mathrm{cA}$ & $63.23 \pm 4.16 \mathrm{cA}$ & $62.93 \pm 2.44 \mathrm{bA}$ & $64.63 \pm 2.34 \mathrm{bA}$ \\
\hline Cucumber & $194.4 \pm 2.11 \mathrm{fA}$ & $192.0 \pm 1.83 \mathrm{fA}$ & $192.5 \pm 2.52 \mathrm{fA}$ & $193.75 \pm 0.96 \mathrm{eA}$ & $192.0 \pm 2.83 \mathrm{eA}$ \\
\hline Carrot & $88.95 \pm 2.78 \mathrm{eA}$ & $87.60 \pm 1.76 \mathrm{eA}$ & $89.88 \pm 3.13 \mathrm{eA}$ & $87.70 \pm 2.39 \mathrm{dA}$ & $89.58 \pm 2.61 \mathrm{dA}$ \\
\hline Arugula & $333.6 \pm 4.65 \mathrm{fA}$ & $331.50 \pm 4.80 \mathrm{fA}$ & $336.0 \pm 3.83 \mathrm{fA}$ & $333.5 \pm 4.65 \mathrm{fA}$ & $331.25 \pm 3.20 \mathrm{fA}$ \\
\hline Parsley & $62.78 \pm 3.87 \mathrm{cB}$ & $62.65 \pm 3.16 \mathrm{cB}$ & $54.38 \pm 7.39 \mathrm{bA}$ & $63.48 \pm 3.61 \mathrm{bB}$ & $59.05 \pm 4.70 \mathrm{bB}$ \\
\hline Cabbage & $22.07 \pm 1.43 \mathrm{aA}$ & $21.55 \pm 1.03 \mathrm{aA}$ & $22.28 \pm 1.18 \mathrm{aA}$ & $22.85 \pm 1.93 \mathrm{aA}$ & $23.15 \pm 1.75 \mathrm{aA}$ \\
\hline Leek & $57.01 \pm 4.22 \mathrm{bA}$ & $56.73 \pm 4.55 \mathrm{bA}$ & $56.53 \pm 2.59 \mathrm{bA}$ & $59.98 \pm 3.42 \mathrm{bA}$ & $59.15 \pm 2.52 \mathrm{bA}$ \\
\hline
\end{tabular}

${ }^{1}$ vegetable washed with DW or ODW for 60 min, respectively.

Data are expressed as mg gallic acid equivalents (GAE)/100 $\mathrm{g}$ fresh weight of vegetable.

Each value is the mean \pm S.D of three replicates.

Means having different small letters in column or capital letters in row are significantly different $(\mathrm{P}<0.05)$.

Table 4: Effect of temperatures of distilled and ozone water treatments on the level of Vitamin $\mathrm{C}$ of the tested vegetables treated with chlorpyrifos

\begin{tabular}{|c|c|c|c|c|c|}
\hline \multirow[b]{2}{*}{ Commidity } & \multirow[b]{2}{*}{ Without washing } & \multicolumn{2}{|c|}{$25^{\circ} \mathrm{C}$} & \multicolumn{2}{|c|}{$35^{\circ} \mathrm{C}$} \\
\hline & & $\mathbf{D W}^{1}$ & $\mathbf{O Z W}^{1}$ & DW $^{1}$ & $\mathbf{O Z W}^{1}$ \\
\hline Bell pepper & $28.67 \pm 2.65 \mathrm{dA}$ & $27.93 \pm 2.12 \mathrm{dA}$ & $30.03 \pm 2.17 \mathrm{eA}$ & $27.78 \pm 1.02 \mathrm{dA}$ & $27.35 \pm 1.12 \mathrm{dA}$ \\
\hline Tomato & $15.11 \pm 0.65 \mathrm{cA}$ & $14.75 \pm 0.44 \mathrm{bA}$ & $14.93 \pm 0.32 \mathrm{bA}$ & $15.10 \pm 0.27 \mathrm{bA}$ & $14.93 \pm 0.25 \mathrm{bA}$ \\
\hline Cucumber & $2.54 \pm 0.10 \mathrm{aA}$ & $2.50 \pm 0.08 \mathrm{aA}$ & $2.43 \pm 0.05 \mathrm{aA}$ & $2.43 \pm 0.13 \mathrm{aA}$ & $2.45 \pm 0.06 \mathrm{aA}$ \\
\hline Carrot & $3.52 \pm 0.12 \mathrm{aA}$ & $3.50 \pm 0.08 \mathrm{aA}$ & $3.35 \pm 0.13 \mathrm{aA}$ & $3.48 \pm 0.05 \mathrm{aA}$ & $3.45 \pm 0.06 \mathrm{aA}$ \\
\hline Arugula & $22.23 \pm 0.19 \mathrm{bA}$ & $21.85 \pm 0.19 \mathrm{cA}$ & $22.28 \pm 0.19 \mathrm{cA}$ & $22.15 \pm 0.15 \mathrm{cA}$ & $22.70 \pm 0.08 \mathrm{cA}$ \\
\hline Parsley & $107.16 \pm 4.55 \mathrm{fA}$ & $106.25 \pm 4.92 \mathrm{fA}$ & $107.75 \pm 3.86 \mathrm{gA}$ & $108.5 \pm 2.65 \mathrm{fA}$ & $108.75 \pm 2.22 \mathrm{gA}$ \\
\hline Cabbage & $26.89 \pm 2.99 \mathrm{dA}$ & $26.23 \pm 2.11 \mathrm{dA}$ & $26.15 \pm 2.61 \mathrm{dA}$ & $26.00 \pm 2.16 \mathrm{dA}$ & $26.50 \pm 2.45 \mathrm{dA}$ \\
\hline Leek & $35.16 \pm 3.11 \mathrm{eA}$ & $34.58 \pm 3.21 \mathrm{eA}$ & $34.70 \pm 1.67 \mathrm{fA}$ & $33.60 \pm 1.65 \mathrm{eA}$ & $33.90 \pm 1.59 \mathrm{fA}$ \\
\hline
\end{tabular}

${ }^{1}$ vegetable washed with DW or ODW for $60 \mathrm{~min}$, respectively.

Data are expressed as $\mathrm{mg}$ vitamin $\mathrm{C} / 100 \mathrm{~g}$ of fresh weight of vegetable.

Each value is the mean \pm S.D of three replicates.

Means having different small letters in column or capital letters in row are significantly different $(\mathrm{P}<0.05)$.

For the postharvest of fresh fruit ${ }^{[91-110]}, \mathrm{O}_{3}$ can be used as a relatively brief pre-storage or storage treatment in air or water, or as a continuous or an intermittent component of the atmosphere throughout storage transportation ${ }^{[49]}$. 


\section{Conclusion}

Food is the basic necessity of life and its contamination with pesticides is associated with severe effects on the human health. Hence it is pertinent to explore strategies that address this situation of food safety, especially in the developing countries where pesticide contamination is widespread due to indiscriminate usage.

Because vegetables are cultivated for culinary and salad purposes without heat treatments and are commonly consumed by people of different ages all over the world, a higher risk of exposure to pesticides especially in children and other vulnerable individuals may occur. Therefore, the search for a safety method to remove undesired pesticide residues in all the steps of the production and distribution of vegetables chain to decrease the intake of pesticide residues as well as to preserve the most of the essential vegetable nutrients has always been preferred.

In the present study, chlorpyrifos residues were significantly degraded and its residual levels in vegetables were reduced by water and/or $\mathrm{O}_{3}$ at all the tested time intervals compared with unwashed-fruits and $\mathrm{O}_{3}$ treatment was more potent than water wash treatment to remove these residues. By the end of the experiment about $83-100 \%$ and $50-100 \%$ of the initial levels of chlorpyrifos residues at 25 and $35{ }^{\circ} \mathrm{C}$ were removed in $\mathrm{O}_{3}$-washed vegetables. When the temperature of ozonated water was $25^{\circ} \mathrm{C}$, the efficacy in chlorpyrifos degradation was increased by prolonging the contact time, while when the temperature of ozonated water increased to $35^{\circ} \mathrm{C}$, the efficacy of chlorpyrifos degradation was not increased by prolonging the contact time. Thus, the results of the present study indicate that it is unfeasible to use ozonated water at high temperature (e.g. $35^{\circ} \mathrm{C}$ ) to degrade chlorpyrifos from vegetables. Also, the present study illustrates that the quantity of chlorpyrifos retained by vegetables varies with the kind of vegetables, where arugula had the highest initial level and bell pepper had the lowest one. The levels of natural waxing and properties of vegetables impact the quantity of pesticide retained by these vegetables.

Due to its high oxidability, high reaction rate, absence of intermediate or dead-end product detected, and instability with a large proportion of it would escape to the ambient or reduce to oxygen molecules in a few minutes without leaving a residue, ozonolysis technique should be used in pesticide-treated vegetables to remove residues adhering on the vegetable's surface without significant changes in antioxidant capacity, total phenolic and vitamin $\mathrm{C}$. Therefore, the present study validated that ozone as wash treatment is safe and promising process for the removal of chlorpyrifos from the vegetable's surface. The results found in the present study must not be extrapolated to other pesticides, vegetables or conditions.

\section{References}

1. Abou-Arab, A.A.K. Behavior of pesticides in tomatoes during commercial and home preparation. (1999) Food Chem 65(4): 509-514. CrossRef|Others

2. Al-Farsi, M., Alasalvar, C., Al-Abid, M., et al. Compositional and functional characteristics of dates, syrups and their by-products. (2007) Food Chem 104(3): 943-947.

CrossRef|Others

3. Allaith, A.A. Antioxidant activity of Bahraini date palm (Phoenix dactylifera L.) fruit of various cultivars. (2008) Inter J Food Sci Technol 43(6): 1033-1040.

CrossRef|Others

4. Alothman, M., Bhupinder, K., Fazilah, A., Ozone-induced changes of antioxidant capacity of fresh-cut tropical fruits. (2010) Innovat Food Sci Emer Techn 11(4): 666-671.

CrossRef|Others

5. Al-Rehiayan, S., Osman, K.A. Residual levels of preharvest-sprayed amitraz in date fruits. (2003) J Pest Cont Environ Sci 11: 1-12.

6. Al-Rehiayani, S., Osman, K.A. Fate of preharvest-prayed dicofol in date fruits: Residue analysis by HPLC. (2005) Agric Mar Sci 10: 21-26. 7. Al-Showiman, S.S. Fayadh, J.M. Chemical composition of date palm (Phoenix dactylifera L). (1990) J Chem Soc Pak 12(1): 84-103.

Others

8. Anonymous. Some important microbial pathogens associated with foodborne illness. (2001) National Food Safety Initiative.

9. Anonymous. The fruit of the desert-Saudi sate market. (2004) Agri Cooper Assoc (7)

Others

10. Artés-Hernández, F., Aguayo, E., Artés, F. Enriched ozone atmosphere enhances bioactive phenolics in seedless table grapes after prolonged shelf life. (2007) J Science Food Agricult 87(5): 824-831.

CrossRef

11. Bajwa, U., Sandhu, K.S. Effect of handling and processing on pesticide residues in food- a review. (2011) J Food Sci Technol 51(2): 201220.

PubMed | CrossRef $\mid$ Others

12. Benitez, F.J, Acero, J.L, Real, F.J. Degrading of carbofuran by using ozone, UV, radiation and advanced oxidation processes. (2002) J Hazard Mater 89(1): 51-65.

PubMed | CrossRef | Others

13. Besbes, S., Drira, L., Blecker, C. et al. Adding value to hard date (Phoenix dactylifera L.): Compositional, functional and sensory characteristics of date jam. (2009) Food Chem 112(2): 406-411.

CrossRef|Others

14. Beuchat, L.R. Surface decontamination of fruits and vegetables: A review. (1998) World Health Organization.

Others

15. Biglari, F., Alkarkhi, A.F.M. Easa, A.M. Antioxidant activity and phenolic content of various date palm (Phoenix dactylifera) fruits from Iran. (2008) Food Chem 107(4): 1636-1641.

CrossRef| Others

16. Botondi, R., Sanctis De, F., Moscatelli, N., et al. Ozone fumigation for safety and quality of wine grapes in postharvest dehydration. (2015) Food Chem 188(1): 641-647.

PubMed |CrossRef | Others

17. Brand-Williams, W., Cuvelier, M.E, Berset, C. Use of a free radical method to evaluate antioxidant activity. (1995) Food Sci Tech 28: 2530 .

CrossRef|Others

18. Brillas, E., Calpe, J.C. Casado, J. Mineralization of 2,4-D by advanced electrochemical oxidation processes. (2000) Water Res 34(8): 2253-2262.

CrossRef|Others 
19. Cengiz, M.F., Certel, M., Gocmen, H. Residue contents of DDVP (Dichlorvos) and diazinon applied on cucumbers grown in greenhouses and their reduction by duration of a pre-harvest interval and post-harvest culinary applications. (2006) Food Chem 98(1): 127-135.

CrossRef|Others

20. Chelme-Ayala, P., Gamal El-Din, M., Smith, D.W. Oxidation kinetics of two pesticides in natural waters by ozonation and ozone combined with hydrogen peroxide. (2011) Water Res 45(8): 2517-2526.

PubMed | CrossRef | Others

21. Codex Alimentarius, Pesticide Residues in Food, Maximum Residue Levels. (2008) Food Agricult Organ.

22. Coke, A.L. Mother nature's best remedy: Ozone. (1993) Water Cond Pur 48-51.

23. Connor, A.M., Luby, J.J., Hancock, J.F., et al. Changes in fruit antioxidant activity among blueberry cultivars during cold temperature storage. (2002) J Agric Food Chem 50(4): 893-898.

PubMed | CrossRef |Others

24. Considine, D. Foods and food production encyclopedia. (1982) Van Nostrand Reinhold 542-550.

CrossRef|Others

25. Costa, L.G., Olibet, G., Murphy, S.D. Alpha-2-adrenoceptors as a target for formamaidine pesticides. In vitro and in vivo studies in mice. (1988) Toxicol Appl Pharmacol 93(2): 319-328.

PubMed | CrossRef|Others

26. Costat Program Costat Statistical Package for Analysis of Variance, Version 2, Cohort Software, Minneapolis. (1986) MN, USA.

27. Doong, R., Chang, W. Photo assisted iron compound catalytic degradation of organophosphorous pesticides with hydrogen peroxide. (1998) Chemosphere 37(13): 2563-2572.

CrossRef|Others

28. Dubois, M., Gilles, K.A., Hamilton, J.K. et al. Colorimetric method for determination of sugars and related substances. (1956) Analyt Chem 28(3): $350-356$

Others

29. Ecobichon, D.J. Toxic effects of pesticides. (1996) Casarett Doull's toxicology 643-698.

30. Ekström, G., Hemming, H., Palborg, M. Swedish pesticide risk reduction 1985-1995: Food residues, health hazard and reported poisonings. (1996) Rev Environ Contam Toxicol 147: 119-147.

PubMed | CrossRef | Others

31. Environmental Protection Agency (EPA) (1996) Registration Eligibility Decision (RED): Amitraz. R.E.D. Facts. United States-Environmental Protection Agency. EPA-736-F-96-031.

32. European Commission (EC) (2008). Maximum pesticide levels for food products for human consumption and animal feeding stuffs, European Union. (2008). Brussels.

Others

33. FAO/WHO. Pesticide Residues in Food. (1981). FAO Plant Prod Protec 42.

Others

34. Flood, A., Velie, E.M., Chaterjee, N.S., et al. Fruit and vegetable intakes and the risk of colorectal cancer in the Breast Cancer Detection Demonstration Project follow-up cohort. (2002) Am J Clini Nutr 75(5): 936-943.

PubMed | Others

35. FAO/WHO (1985). Pesticide Residues in Food. Evaluations. (1984)

FAO Plant Prod Protec 67.

Others

36. Forney, C.F. Postharvest response of horticultural products to ozone. In Postharvest Oxidative Stress in Horticultural Crops. (2003) Food Products 13-54.

37. Gallard, J., De Laat, J. Kinetics of oxidation of chlorobenzenes and phenyl-ureas by $\mathrm{Fe}(\mathrm{II}) / \mathrm{H} 2 \mathrm{O} 2$ and $\mathrm{Fe}(\mathrm{III}) / \mathrm{H} 2 \mathrm{O} 2$. Evidence of reduction and oxidation reactions of intermediates by $\mathrm{Fe}(\mathrm{II})$ or $\mathrm{Fe}(\mathrm{III})$. (2001) Chemosphere 42(4): 405-413.

PubMed | CrossRef|Others
38. Glaze, W.H., Kang, J.W., Chapin, D.H. The chemistry of water treatment processes involving ozone, hydrogen peroxide and ultraviolet irradiation. (1987) Ozone Sci Engin 9(4): 335-352.

CrossRef|Others

39. Graham, D.M. Use of ozone for food processing. (1997) Food Techn 51: 121-137.

PubMed | CrossRef $\mid$ Others

40. Gottschalk, C., Libra, J.A., Saupe, A. Ozonation of Water and Waste Water. A Practical Guide to Understanding Ozone and its Application. (2000) WILEY-VCH Verlag GmbH : 2-23.

CrossRef|Others

41. Guo, A., Yang, J., Wei, J. et al. Antioxidant activities of peel, pulp and seed fractions of common fruit as determined by FRAP assay. (2003) Nutr Res 23(12): 1719-1726.

CrossRef|Others

42. Gupta, R.C. Veterinary Toxicology. (2007) Elsevier Inc.

Others

43. Guzel-Seydim, Z.B., Green, A.K., Seydim, A.C. Use of ozone in the food industry. (2004) Food Scienc Techn 37(4): 453-460.

CrossRef|Others

44. Heijman, S.G.J., Hopman, R. Activated carbon filtration in drinking water production: model prediction and new concepts. (1999) Colloids and Surfaces A: Physicochemical and Engineering Aspects151(1-2): 303-310.

CrossRef|Others

45. Hill, A.G, Rice, R.G. Historical background properties and applications. In Ozone Treatment of Water for Cooling Application. (1982) Ann Arbor Sci 1-37.

46. Hoigne, J. Bader, H. Rate constants of reactions of ozone with organic and inorganic compounds in water-1 non-dissociating organic compounds. (1983) Water Res 17(2): 173-183.

CrossRef|Others

47. Huxley, R.R., Lean, M., Crozier, A., et al. Effect of dietary advice to increase fruit and vegetable consumption on plasma flavonol concentrations: Results from a randomised controlled intervention trial. (2004) J Epidemiol Community Health 58(4): 288-289.

PubMed |CrossRef|Others

48. Hwang, E., Cash, J.N., Zabik, M.J. et al. Postharvest treatments for the reduction of mancozeb in fresh apples. (2001) J Agric Food Chem 49(6): 3127-3132.

PubMed | CrossRef | Others

49. Isikber, A.A., Athanassiou, C.G. The use of ozone gas for the control of insects and micro-organisms in stored products. (2014) J Stored Products Res 64: 139-145.

CrossRef|Others

50. Ismail, B., Haffar, I., Baalbaki, R. et al. Physico-chemical characteristics and sensory quality of two date varieties under commercial and industrial storage conditions. (2008) LWT-Food Sci Tec 41(5): 896-904. CrossRef|Others

51. Jorens, P.G., Zandijk, E., Belmans, L., et al. An unusual poisoning with the unusual pesticide amitraz. (1997) Hum Exp Toxicol 16(10): 600-601.

PubMed $\mid$ CrossRef $\mid$ Others

52. Kamel, A., Al-Dosary, S., Ibrahim, S. Degradation of the acaricides abamectin, flufenoxuron and amitraz on Saudi Arabian dates. (2007) Food Chem 100(4): 1590-1593.

CrossRef

53. Karaca, H., Velioglu, Y. S. Ozone applications in fruit and vegetable processing. (2007) Food Rev Inter 23(1): 91-106.

CrossRef|Others

54. Karaca, H., Walseb, S.S, Smilanick, J.L. Effect of continuous $0.3 \mu \mathrm{L} / \mathrm{L}$ gaseous ozone exposure on fungicide residues on table grape berries. (2012) Postharvest Biol Technol 64(1): 154-159.

CrossRef|Others

55. Kaushik, G., Satya, S., Naik, S.N. Food processing a tool to pesticide residue dissipation-A review. (2009) Food Res Inter 42(1): 26-40. CrossRef|Others 
56. Kitajama, E.W., Rezende, J.A., Rodrigues, J.C. Passion fruit green spot virus vectored by Brevipalpus phoenicis (Acari: Tenuipalpidae) on passion fruit in Brazil. (2003) Exp Appl Acarol 30(1-3): 225-231.

PubMed

57. Kosanić, M., Ranković, B., Vukojević, J. Antioxidant properties some lichen species. (2011) J Food Sci Technol 48(5): 584-590.

PubMed

58. Kouloumbos, V.N., Tsipi, D.F., Hiskia, A.E., et al. Identification photocatalytic degradation products of diazinon on $\mathrm{TiO} 2$ aqueous suspensions using GC/MS/MS and LC/MS with quadrupole time of-flight mass spectrometry. (2003) J Am Soc Mass Spectrom 14(8): 803-817.

PubMed | CrossRef | Others

59. Krol, W.J., Arsenault, T.L., Pylypiw, H.M. et al. Reduction of pesticide residues on produce by Rinsing. (2000) J Agric Food Chem 48(10): 4666-4670.

PubMed

60. Kulkarni, S.G., Vijayanand, P., Shubha, L. Effect of processing of dates into date juice concentrate and appraisal of its quality characteristics. (2010) J Food Sci Technol 47(2): 157-161.

PubMed|Others

61. Kuo, W.S. Destruction of toxic organics in water by an injection-type down flow UV/O3 oxidation reactor. (1999) Ozone Sci Eng 21(5): 539-550.

CrossRef|Others

62. Lafi, W.K., Al-Qodah, Z. Combined advanced oxidation and biological treatment processes for the removal of pesticides from aqueous solutions. (2006) J Hazard Mater 137(1): 489-497.

PubMed | CrossRef | Others

63. Laurila, E., Ahvenainen, R. Minimal processing of fresh fruits and vegetables. (2002) Fruit Veg Processing

PubMed |CrossRef $\mid$ Others

64. Lee, S.R., Mourer, C.R., Shibamoto, T. Analysis before and after cooking processes of a trace chlorpyrifos spiked in polished rice. (1991) J Agric Food Chem 39(5): 906-908.

PubMed $\mid$ CrossRef $\mid$ Others

65. Legrini, O., Oliveros, E., Braun, A.M. Photochemical processes for water treatment. (1993) Chem Rev 93(2): 671-698.

CrossRef|Others

66. Liu, Y.H., Liu, Y., Chen, Z.S. Purification and characterization of a novel organophosphorus pesticide hydrolase from Penicillium lilacimum PB303. (2004) Enzy Microb Technol 34(3-4): 297-303.

CrossRef|Others

67. Mansouri, A., Embarek, G., Kokkalou, E., et al. Phenolic profile and antioxidant activity of the Algerian ripe date palm fruit (Phoenix dactylifera). (2005) Food Chem 89(3): 411-420.

CrossRef|Others

68. Martel, A.C., Zeggane, S. Determination of acaricides in honey by high-performance liquid chromatography with photodiode array detection. (2002) J Chromatogr A 954(1-2): 173-180.

PubMed | CrossRef|Others

69. Masten, S.J., Davies, S.H. The use of ozonation to degrade organic contaminants in waste waters. (1994) Environ Sci Technol 28(4): 180A-185A.

CrossRef|Others

70. Meijers, R.T., Oderwald-Muller, E.J. Degradation of pesticides by ozonation and advanced oxidation. (1995) Ozone Sci Eng 17(6): 673686.

CrossRef | Others

71. Moldaum, J.H. A simple existence proof of demand functions without standard transitivity. (1966) J Math Econ 25(3): 325-333.

CrossRef|Others

72. Moore, J.A. Intent to cancel registrations of pesticide products containing dicofol: Denial of applications for registration of pesticide products containing dicofol; Conclusion of special review. (1986) Fed Reg 51: $19508-19525$
73. Moser, V.C., Macphail, R.C. Investigations of amitraz neurotoxicity in rats. Effects on motor activity and inhibition of monoamine oxidase. (1989) Fundam Appl Toxicol 12(1): 12-22.

PubMed | CrossRef| Others

74. Mourer, C.R., Hall, G.L., Whitehead, W.E., et al. Chromatographic determination of dicofol and metabolites in egg yolks. (1990) Arch Environ Contam Toxicol 19(1): 154-156.

PubMed | CrossRef | Others

75. Ong, K.C., Cash, J.N., Zabik, M.J., et al. Chlorine and ozone washes for pesticide removal from apples and processed apple sauce. (1996) Food Chem 55(2): 153-160.

CrossRef|Others

76. Ormad, M.P., Miguel, N., Claver, A. Pesticides removal in the process of drinking water production. (2008) Chemo 71(1): 97-106.

PubMed | CrossRef | Others

77. Ormad, P., Cortés, S., Puig, A., et al. Degradation of organochloride by $\mathrm{O}_{3}$ and $\mathrm{O}_{3} / \mathrm{H}_{2} \mathrm{O}_{2}$. (1997) Water Res 31(9): 2387-2391.

CrossRef|Others

78. Osman, K.A. Pesticides and human health. (2011) InTech Publisher, Croatia 11: 205-230.

CrossRef|Others

79. Osman, K.A., Al-Rehiayan, S. Risk assessment of pesticide to human and the environment. (2003) Saudi J Biol Sci 10: 81-106.

80. Osman, K.A., Al-Humaid, A.I., Al-Redhaiman, K.N. Safety methods for chlroyprifos removal from date fruits and its relation with sugars, phenolics and antioxidant capacity of fruits. (2012) J Food Sci Technol 49: 1-11.

PubMed | CrossRef

81. Osman, K.A., Al-Rehiayani, S., Al-Doghairi, M.A. et al. Bioremediation of oxamyl in sandy soil using animal manures. (2009) Inter Biodeter Biodegrad 63(3): 341-346.

Others

82. Palou, L., Crisosto, C.H., Smilanick, J.L., et al. Effect of continuous $0.3 \mathrm{ppm}$ ozone exposure on decay development and physiological responses of peaches and table grapes in cold storage. (2002) Postharvest Biol Technol 24(1): 39-48.

CrossRef|Others

83. Peleg, M. The chemistry of ozone in the treatment of water. (1976) Water Res 10(5): 361-365.

CrossRef|Others

84. Pugliese, P., Moltó, J.C., Damiania, P. Gas chromatographic evaluation of pesticide residue contents in nectarines after non-toxic washing treatments. (2004) J Chromatoqr A 1050(2): 185-191.

PubMed | CrossRef | Others

85. Queiroz-Neto, A., Juang, S.J., Souza, K.R., et al. Antinociceptive effect of amitraz in mice and rats. (1994) Braz J Med Biol Res 27(6): 1407-1411.

PubMed | Others

86. Reynolds, G., Graham, N., Perry, R., et al. Aqueous ozonation of Fatty Acids. (1989) Ozone Sci Engin 11: 339-382.

CrossRef|Others

87. Rice, R.G., Bollyky, L.J., Lacy, W.J. Analytical Aspects of Ozone Treatment of Water and Waste Water. (1986) The institute: New York 7-26.

CrossRef|Others

88. Savi, G.D., Piacentini, K.C., Scusse, V.M. Reduction in residues of deltamethrin and fenitrothion on stored wheat grains by ozone gas. (2015) J Stored Products Res 61: 65-69.

CrossRef|Others

89. Schreinemachers, P., Tipraqsa, P. Agricultural pesticides and land use intensification in high, middle and low income countries. (2012) Food Policy 37(6): 616-626.

CrossRef|Others

90. Selma, M.V., Ibáńeza, A.M., Allendeb, A., et al. Effect of gaseous ozone and hot water on microbial and sensory quality of cantaloupe and potential transference of Escherichia coli O157:H7 during cutting. 
(2008) Food Microbiol 25(1): 162-168.

PubMed |CrossRef | Others

91. Singleton, V.L., Rossi, J.A. Colorimetry of total phenolics with phosphomolybdic-phosphotungstic Acid Reagents. (1965) Am J Enol Vitic 16: 144-158.

Others

92. The Royal Society of Chemistry. The Agrochem. (1988)

93. Tomlin, C.D.S. The e-Pesticide Manual. (2002) British Crop Prot Coun.

94. Tiwari, B.K., Brennan, C.S., Curran, T. Application of ozone in grain processing. (2010) J Cer Sci 51(3): 248-255.

CrossRef|Others

95. Tzortzakis, N., Borland, A., Singleton, I. et al. Impact of atmospheric ozone-enrichment on quality-related attributes of tomato fruit. (2007) Postharvest Bio Technol 45(3): 317-325.

CrossRef|Others

96. Ulukaya, S., Demirag, K., Moral, A.R. Acute amitraz intoxication in human. (2001) Intensive Care Med 27(5): 930-933.

PubMed | CrossRef | Others

97. USDA. Temperatures and Chilling and Freezing Procedures. (1997)

Fed Regist Nat Arch Rec Admin.

98. Van Dijck, P.J., Voorde, D.V.H. Biodegradation of methoxychlor and kelthane. (1976) Europ J Appl Microb 2(4): 277-284.

CrossRef|Others

99. Vayalil, P.K. Antioxidant and antimutagenic properties of aqueous extract of date fruit (Phoenix dactylifera L. arecaceae). (2002) J Agric Food Chem 50(3): 610-617.

PubMed | CrossRef | Others

100. Walling, C. Fenton's reagent revisited. (1975) Acc Chem Res 8(4):

125-131.

CrossRef|Others

101. Walsh, P.R., Hites, R.A. Dicofol solubility and hydrolysis in water. (1979) Bull Environ Contam Toxicol 22(1): 305-311.

PubMed | CrossRef | Others

102. Wang, H., Cao, G., Prior, R.L. Total antioxidant capacity of fruits. (1996) J Agric Food Chem 44(3): 701-705.

CrossRef|Others
103. Wang, Q.Q., Lemley, A.T. Oxidation of diazinon by anodic Fenton treatment. (2002) Water Res 36(13): 3237-3244.

PubMed | CrossRef | Others

104. Wiemeyer, S.N., Clarck, D.R., Spann J.W., et al. Dicofol residues in eggs and carcasses of captive American kestrels. (2001) Environ Toxicol Chem 20(12): 2848-2851.

PubMed | CrossRef| Others

105. Wu, C., Linden, K.G. Degradation and byproduct formation of parathion in aqueous solutions by UV and UV/H2O2 treatment. (2008)

Water Res 42(19): 4780-4790.

PubMed | CrossRef

106. Wu, J.G., Luan, T.G., Lan, C.Y., et al. Efficacy evaluation of low-concentration of ozonated water in removal of residual diazinon, parathion, methyl-parathion and cypermethrin on vegetables. (2007) J Food Engin 79(3): 803-809.

CrossRef|Others

107. Yao, C.C.D., Haag, W.R. Rate constants of direct ozone reactions with several drinking water contaminants. (1991) Water Res 25(7): 761-773.

\section{CrossRef|Others}

108. Yaramis, A., Soker, M., Bilici. M. Amitraz poisoning in children. (2000) Hum Exp Toxicol 19(8): 431-433.

Others

109. Zhang, L., Guo, X., Yan, F. Study of the degradation behaviour of dimethoate under microwave irradiation. (2007) J Hazard Mater 149(3): 675-679.

CrossRef|Others

110. Zhang, L., Liu, X-J., Hong, X-Y. Effects of home preparation on pesticide residues in cabbage. (2007) Food Cont 18(12): 1484-1487. CrossRef|Others
Online ISSN: 2377-0619

Journal Title: International Journal Food and Nutritional Science Journal Short Name: Int J Food Nutr Sci
Ommega Online Publishers

E-mail: editor.foodscience@ommegaonline.com Website: www.ommegaonline.org 